\title{
PENGARUH MODEL PEMBELAJARAN KOOPERATIF TIPE NUMBERED HEAD TOGETHER (NHT) TERHADAP PEMAHAMAN KONSEP PESERTA DIDIK KELAS VII SMP NEGERI 18 MAKASSAR (Studi Pada Materi Pokok Tata Surya)
}

Ratnawaty Mamin Universitas Negeri Makassar

Sudarto Universitas Negeri Makassar

Rahmita Universitas Negeri Makassar
Abstrak: Penelitian ini adalah Penelitian eksperimental-Semu (QuasiExperimental Research) bertujuan untuk mengetahui: (1) seberapa tinggi tingkat pemahaman konsep peserta didik setelah diajar melalui model pembelajaran Kooperatif Tipe Numbered Head Together (NHT), (2) seberapa tinggi tingkat pemahaman konsep peserta didik setelah diajar melalui model pembelajaran konvensional, (3) apakah terdapat pengaruh model pembelajaran Kooperatif Tipe Numbered Head Together (NHT) terhadap pemahaman konsep peserta didik kelas VII SMP Negeri 18 Makassar (Studi Pada Materi Pokok Tata Surya) tahun ajaran 2016/2017. Metode penelitian yang digunakan adalah metode Quasi-eksperiment dengan menggunakan desain penelitian Pretest-Posttest Nonequivalent Control Group Design. Populasi penelitian ini adalah peserta didik kelas VII SMP Negeri 18 Makassar semester genap tahun pelajaran 2016/2017 yang terdiri dari sepuluh kelas dengan jumlah peserta didik 300 orang. Adapun Sampel penelitian ini sebanyak dua kelas yaitu kelas VII.7 sebagai kelas eksperimen dan kelas VII.9 sebagai kelas kontrol yang dipilih secara acak dengan asumsi bahwa seluruh kelas adalah homogen. Teknik pengumpulan data yang dilakukan dalam penelitian ini dengan menggunakan istrumen penelitian yakni tes pemahaman konsep dan lembar observasi keterlaksanaan model. Tes yang digunakan adalah pretest dan posttest dalam bentuk tes objektif. Data yang diperoleh diolah menggunakan analisis statistik deskriptif dan statistik inferensial untuk kedua kelas. Berdasarkan hasil analisis data untuk kelas eksperimen memperoleh nilai rata-rata sebesar 85,83 kategori sangat tinggi dan kelas kontrol memperoleh nilai rata-rata sebesar 77,66 tinggi. Berdasarkan hasil penelitian diperoleh bahwa (1) Tingkat pemahaman konsep peserta didik yang diajar menggunakan model pembelajaran kooperatif tipe Numbered Head Together (NHT) berada pada kategori sangat tinggi, (2) Tingkat pemahaman konsep peserta didik yang diajar menggunakan model pembelajaran konvensional berada pada kategori tinggi, (3) Terdapat pengaruh model pembelajaran Kooperatif Tipe Numbered Head Together (NHT) terhadap pemahaman konsep peserta didik kelas VII SMP Negeri 18 Makassar (Studi Pada Materi Pokok Tata Surya) tahun ajaran 2016/2017.

Kata Kunci : Kooperatif, Numbered Head Together (NHT), Pemahaman Konsep

Abstract: This research is Quasi-Experimental Research aims to know: This study aims to: (1) how high the level of understanding of the concept of 
learners after being taught through cooperative learning model Numbered Head Together (NHT), (2) how high the level of understanding the concept of learners after being taught through conventional learning model, 3 ) whether there is influence of cooperative learning model Numbered Head Together $(\mathrm{NHT})$ to understanding the concept of students of class VII of SMP Negeri 18 Makassar (Study on the subject matter of the Solar System) academic year 2016/2017. The research method used is Quasi-experiment method using Pretest-Posttest Nonequivalent Control Group Design. The population of this study is the students of class VII of SMP Negeri 18 Makassar in the even semester of the academic year 2016/2017 consisting of ten classes with 300 students. The sample of this research as much as two classes of class VII.7 as experimental class and class VII.9 as a control class selected at random with the assumption that the whole class is homogeneous. Data collection techniques conducted in this study by using research instrument that is concept comprehension test and observation sheet model implementation. The tests used are pretest and posttest in the form of objective tests. The data obtained were processed using descriptive statistical analysis and inferential statistics for both classes. Based on the result of data analysis for experiment class get the average value equal to 85,83 in very high category and control class get average value equal to 77,66 in high. Based on the results of the research, it is found that (1) the level of understanding of the concepts of learners who are taught using cooperative learning model of Numbered Head Together (NHT) type is very high, (2) The level of understanding of learners' concepts taught using conventional learning model is in high category , (3) There is influence of cooperative learning model Numbered Head Together (NHT) to the understanding of the concept of students of class VII of SMP Negeri 18 Makassar (Study on the subject matter of the Solar System) of academic year 2016/2017.

Keywords: Cooperative, Numbered Head Together (NHT), Concept Understanding.

\section{PENDAHULUAN}

Keberhasilan pendidikan di Indonesia terus diupayakan oleh pemerintah dengan melakukan perombakan dan pembaharuan pendidikan dengan tujuan agar sistem yang ada dapat bermanfaat serta tujuan dari pendidikan dapat tercapai. Namun, keberhasilan tersebut berkaitan dengan proses pembelajaran yang berlangsung di sekolah dengan melibatkan pendidik, peserta didik dan meteri pelajaran. Dalam proses pembelajaran pendidik melakukan berbagai upaya yang dapat mendukung tercapainya tujuan pembelajaran, mulai dari perancanaan pembelajaran, pemilihan materi ajar, penyesuaian strategi/metode /model/teknik pembelajaran yang sesuai dengan materi dan kondisi peserta didik.

Kurikulum 2013 yang telah diterapkan di berbagai wilayah Indonesia merupakan kurikulum yang menekankan pada keaktifan peserta didik. Kurikulum ini dianggap dapat memberikan proses belajar mengajar secara efektif dan peserta didik dapat mengalami proses pembelajaran yang bermakna. Selain itu, melalui penerapan kurikulum tersebut, proses interaksi aktif dapat terjadi 
antara peserta didik, guru dan materi pembelajaran. Oleh karena itu, perlu adanya suatu model pembelajaran yang dapat diterapkan untuk mencapai keberhasilan dalam proses pembelajaran. Kenyataan rendahnya daya serap peserta didik menjadi salah satu masalah pokok dalam pembelajaran pada pendidikan formal (sekolah) dewasa ini. Tampak dari ratarata hasil belajar peserta didik yang masih memprihatinkan. Hal ini disebabkan proses pembelajaran hingga dewasa ini masih memberikan dominasi pendidik dan tidak memberikan akses bagi peserta didik untuk berkembang secara mandiri dalam proses berpikirnya (Susanto, 2012).

Dalam pelaksanaan kurikulum saat ini, salah satu pembelajaran yang sering digunakan di sekolah menengah pertama adalah pembelajaran konvensional yang hanya berorientasi pada penguasaan materi dan pendidik sebagai pusat utama dalam proses pembelajaran di kelas (teacher centered bukannya student centered), hal ini yang mengakibatkan peserta didik dominan dalam menghafal informasi bukannya memahami apa yang dipelajarinya. Pembelajaran konvensional mengakibatkan peserta didik tidak terlibat aktif dalam proses pembelajaran, mereka hanya terkesan mendengarkan materi yang disampaikan oleh pendidik tanpa adanya peran aktif peserta didik secara mendalam dalam proses pembelajaran. Jika peserta didik terlibat dalam pembelajaran maka dia akan lebih memaknai dan lebih memahami setiap materi yang diajarkan, untuk menunjang keberhasilan dalam pembelajaran pendidik haruslah lebih kreatif dan inovatif dalam penyajian materi yang dapat melibatkan keaktifan peserta didik.

Pencapaian keberhasilan dalam pendidikan dapat dilihat dari hasil belajar yang telah diperoleh peserta didik selama mengikuti proses pembelajaran. Hasil belajar dapat meningkat jika penerapan model pembelajaran juga tepat. Namun, pada kenyataannya masih ditemukan pada beberapa sekolah yang belum mampu meningkatkan hasil belajar peserta didik yang dimilikinya. Beberapa contoh masalah yang ditemukan yaitu masih banyak peserta didik yang mengalami kesulitan belajar, khususnya dalam mata pelajaran IPA Terpadu pada materi sistem ekskresi manusia. Materi sistem ekskresi penting untuk dipelajari oleh peserta didik, mengingat bahwa sistem ekskresi dialami dan terdapat pada tubuh manusia itu sendiri. Namun, pada kenyataannya peserta didik kurang paham pada materi tersebut. Hal ini terjadi karena persoalan konsep dalam proses pembelajaran.

Masalah tersebut juga dialami SMP Negeri 18 Makassar yang memberikan bukti bahwa pembelajaran di sekolah tersebut belum maksimal seperti yang diharapkan. Hal ini terlihat pada Kriteria Ketuntasan Minimal (KKM) peserta didik yang masih kurang dari standar nilai yang ditetapkan di sekolah, yaitu 78,00. Pada SMPN 18 Makassar dengan melihat ketuntasan peserta didik pada materi tersebut yakni 70\% peserta didik dinyatakan memenuhi standar KKM dan 30\% peserta didik tidak memenuhi standar KKM sehigga perlu diterapkannya model pembelajaran yang dapat meningkatkan jumlah peserta didik yang tuntas. Mengatasi masalah tersebut, maka perlu adanya suatu tindak lanjut dimana pembelajaran kooperatif diharapkan mampu meningkatkan pemahaman konsep peserta didik di SMP Negeri 18 Makassar pada materi pokok tata surya.

Pelaksanaan pembelajaran kooperatif menjadi salah satu model pembelajaran yang mendukung pelaksanaan kurikulum 2013. Pembelajaran kooperatif tidak hanya bertujuan untuk menyelesaikan tugas yang diberikan pada kelompok tersebut melainkan merupakan model pembelajaran yang menekankan pada tanggung jawab belajar individu dalam kelompok (Sanjaya, 2006). Pembelajaran kooperatif merupakan sistem pengajaran yang memberi kesempatan kepada anak didik untuk bekerja sama dengan sesama peserta didik dalam tugas-tugas yang terstruktur. Menurut Lie (Taniredja, 2012) bahwa model pembelajaran kooperatif tidak sama dengan sekedar belajar dalam kelompok. Ada unsur-unsur dasar pembelajaran cooperative learning yang membedakannya dengan pembagian kelompok yang dilakukan asal-asalan. Pelaksanaan prosedur model cooperative learning dengan benar-benar akan memungkinkan pendidik mengelola kelas dengan lebih efektif.

Model pembelajaran kooperatif dikembangkan untuk mencapai setidak-tidaknya tiga tujuan pembelajaran penting. Menurut depdiknas tujuan pertama pembelajaran kooperatif, yaitu 
meningkatkan hasil akademik, sedangkan tujuan kedua memberi peluang agar peserta didik dapat menerima teman-temannya yang mempunyai berbagai perbedaan latar belajar, kemudian tujuan ketiga untuk mengembangkan keterampilan social peserta didik (Taniredja, 2012).

Salah satu pendekatan atau strategi dalam model pembelajaran kooperatif ialah model pembelajaran tipe Numbered Head Together (NHT). NHT atau kepala bernomor merupakan salah satu tipe model pembelajaran dari model pembelajaran kooperatif, yang dikembangkan oleh Russ Frank. Model pembelajaran ini memberikan kesempatan kepada setiap peserta didik untuk saling sharing ide-ide dan mempertimbangkan jawaban yang paling tepat sehingga meningkatkan semangat belajar peserta didik. Model ini dapat digunakan untuk semua mata pelajaran dan tingkatan kelas (Huda, 2011).

Model pembelajaran kooperatif terbagi menjadi beberapa macam, diantaranya adalah model pembelajaran kooperatif tipe Numbered Head Together (NHT) dimana model pembelajaran ini memberi kesempatan kepada peserta didik untuk saling membagikan ide-ide dan pertimbangan jawaban yang paling tepat, selain itu teknik ini mendorong peserta didik untuk meningkatkan semangat kerjasama mereka (Isjoni, 2013). Secara umum model pembelajaran NHT terdiri dari empat fase utama, yaitu: 1) Penomoran (numbering), pendidik membagi peserta didik menjadi beberapa kelompok yang terdiri dari lima sampai tujuh orang dan memberi nomor kepala sehingga setiap peserta didik pada masing-masing kelompok memiliki nomor 1 sampai 7. 2) Pengajuan pertanyaan (questioning), pendidik mengajukan sebuah pertanyaan atau permasalahan untuk dipecahkan bersama dalam kelompok. 3) Berpikir bersama (heads together) peserta didik menyatukan "kepalanya" untuk menemukan jawabannya dan memastikan bahwa semua anggota kelompoknya tahu jawabannya. 4) Menjawab (answering), pendidik memanggil sebuah nomor dan peserta didik dari masing-masing kelompok yang memiliki nomor itu mengangkat tangannya dan memberikan jawabannya ke hadapan seluruh teman-temannya yang berada didalam kelas (Trianto, 2012).

Kelebihan dan kekurangan model pembelajaran kooperatif tipe NHT yang disebutkan Ibrahim (Sitorus, 2012) adalah sebagai berikut:

1. Kelebihan model pembelajaran kooperatif tipe NHT yaitu :

a. Peserta didik dapat berinteraksi dalam memecahkan masalah untuk menentukan konsep yang dikembangkan

b. Dapat meningkatkan perolehan isi akademik dan kerampilan sosial

c. Setiap peserta didik memiliki kesiapan belajar

d. Meningkatkan kerampilan berpikir peserta didik baik secara individual maupun kelompok

e. Melatih peserta didik untuk meningkatkan keterampilan berkomunikasi

2. Kekurangan model pembelajaran kooperatif tipe NHT yaitu :

a. Tidak terlalu cocok untuk peserta didik yang banyak

b. Membutuhkan waktu yang lama

c. Tidak semua anggota kelompok dipanggil oleh pendidik

d. Pengkondisian kelas kurang

Pemahaman tentang konsep merupakan aspek penting dalam belajar. Salah satu tujuan mengajar adalah membantu peserta didik memahami konsep utama subjek bukannya hanya mengingat fakta tertentu. Pemahaman konsep meningkat ketika pendidik mampu mengeksplorasi topik secara mendalam dan memberikan contoh yang menarik dan sesuai dengan konsep itu. Dengan demikian, konsep adalah blok bangunan berpikir. Konsep melakukan pengelompokan objek, kejadian, dan karakteristik berdasarkan pada cir-ciri yang umum. Pemahaman akan konsep membantu kita menyederhanakan, meringkas, dan mengorganisasikan informasi. Pemahaman konsep akan memandu kita pada "reinventing the wheel" setiap kali berhadapan dengan sebagian informasi yang baru. Pemahaman akan konsep membantu kita dalam proses mengingat dengan lebih efisien (Tung, 2000). 
Salah satu kategori dalam dimensi proses kognitif taksonomi Bloom yang dikemukakan oleh Anderson \& Krathwohl (2010) adalah memahami. Memahami berarti mengkontruksi makna dari pesan-pesan pembelajaran, baik yang bersifat lisan maupun grafis, yang disampaikan melalui grafis, disampaikan melalui pengajaran, buku, atau layar computer. Peserta didik memahami ketika mereka menghubungkan pengetahuan baru dan pengetahuan lama mereka. Lebih tepatnya, pengetahuan yang baru masuk dipadukan dengan skema-skema dan kerangka-kerangka kognitif yang telah ada. Lantaran konsep-konsep di otak seumpama blok-blok bangunan yang ada di dalamnya berisi skema-skema dan kerangka-kerangka kognitif, Pengetahuan Konseptual menjadi dasar untuk memahami. Proses-proses kognitif dalam kategori memahami meliputi menafsirkan, mencontohkan, mengklasifikasikan, merangkum, menyimpulkan, membandingkan, dan menjelaskan.

Berdasarkan Hasil Penelitian Dari Beberapa Peneliti Tentang Pengaruh Model Pembelajaran Kooperatif Tipe Numbered Head Together (NHT) terhadap pemahaman konsep dilihat dari hasil penelitian Ratnasari (2015) Pengaruh Model Pembelajaran Kooperatif Tipe Numbered Heads Together (NHT) Terhadap Peningkatan Keterampilan Sosial dan Pemahaman Konsep peserta didik dalam Pembelajaran IPA Peserta Didik Kelas VIII SMPN 2 Gamping dimana hasil dari penelitian tersebut menyatakan bahwa Model pembelajaran Cooperative Learning tipe Numbered Heads Together (NHT) berpengaruh terhadap peningkatan pemahaman konsep peserta didik dilihat dari analisa pengaruh keefektifan model pembelajaran Cooperative Learning tipe Numbered Heads Together (NHT) sebesar 6,91\%.

Adapun penelitian lain yang mendukung yaitu penelitian llyasari (2013) yang bejudul Pengaruh Model Pembelajaran Kooperatif Tipe NHT Terhadap Pemahaman Konsep Matematis Peserta Didik Kelas VIII SMPN 7 Bandar Lampung yaitu Pembelajaran kooperatif tipe NHT dapat merangsang peserta didik untuk berperan aktif dalam interaksi pembelajaran di kelas, sehingga peserta didik dapat lebih memahami materi dengan baik. Hal ini ditunjukkan dengan rata-rata nilai pemahaman konsep peserta didik yang mengikuti pembelajaran dengan model kooperatif tipe NHT lebih tinggi daripada rata-rata nilai pemahaman konsep peserta didik yang mengikuti pembelajaran konvensional.

Dengan demikian, diadakan penelitian untuk mengetahui pengaruh model pembelajaran kooperatif tipe Numbered Head Together (NHT) terhadap pemahaman konsep peserta didik kelas VII SMP Negeri 18 Makassar. Rumusan masalah yang digunakan pada penelitian ini yaitu, (1) Seberapa tinggi tingkat pemahaman konsep peserta didik setelah diajar melalui model pembelajaran Kooperatif Tipe Numbered Head Together (NHT)? (2)Seberapa tinggi tingkat pemahaman konsep peserta didik setelah diajar melalui model pembelajaran Konvensional? (3) Apakah terdapat pengaruh model pembelajaran Kooperatif Tipe Numbered Head Together (NHT) terhadap pemahaman konsep peserta didik Kelas VII di SMP Negeri 18 Makassar (Studi Pada Materi Pokok Tata Surya) tahun ajaran 2016/2017?

\section{METODE}

Jenis penelitian yang digunakan dalam penelitian ini ialah Quasi-eksperiment dengan menggunakan desain Pretest-Posttest Nonequivalent Control Group Design. Penelitian dilaksanakan di SMP Negeri 18 Makassar. Populasi penelitian adalah seluruh peserta didik kelas VII SMP Negeri 18 Makassar tahun ajaran 2016/2017 yang terdiri dari sepuluh kelas dengan jumlah peserta didik setiap kelas sebanyak 300 orang. Pemilihan sampel dilakukan dengan teknik double random sampling sehingga diperoleh dua kelas sampel yakni kelas VII.7 sebagai kelas eksperimen dan kelas VII.9 sebagai kelas kontrol.

Teknik pengumpulan data dilakukan dengan pemberian tes pemahaman konsep berupa pilihan ganda yang terdiri dari 25 item yang selanjutnya data akan dianalisis statistik deskriptif dan analisis statistik inferensial. 


\section{HASIL DAN PEMBAHASAN}

\section{Hasil Penelitian}

Hasil pemahaman konsep pada kelas eksperimen dengan menggunakan model pembelajaran kooperatif tipe Numbered Head Together (NHT) mengalami peningkatan lebih tinggi daripada kelas kontrol yang diajar dengan model pembelajaran konvensional. Nilai hasil pemahaman konsep yang dimaksud adalah nilai total hasil tes yang berbentuk tes pilihan ganda pada ranah kognitif C2 yang diperoleh peserta didik baik pada kelas eksperimen maupun pada kelas kontrol.

Tabel 1. Nilai Posttest Pemahaman Konsep pada Kelas Eksperimen dan Kelas Kontrol Peserta Didik Kelas VII SMP Negeri 18 Makassar

\begin{tabular}{ccc}
\hline Data & Kelompok Eksperimen & Kelompok Kontrol \\
\hline Jumlah Sampel & 30 & 30 \\
Skor Tertinggi & 96 & 88 \\
Skor Terendah & 68 & 60 \\
Nilai Rata-rata & 85,83 & 77,66 \\
Standar Deviasi & 8,10 & 8,17 \\
Varians & 65,66 & 66,78 \\
\hline
\end{tabular}

Jumlah perolehan nilai peserta didik pada kelas eksperimen dan kelas kontrol dapat dilihat berdasarkan pengkategorian skor yang disajikan pada tabel berikut.

Tabel 2. Kategori Nilai Posttest Pemahaman Konsep Peserta Didik Kelas Eksperimen dan Kelas Kontrol

\begin{tabular}{|c|c|c|c|}
\hline \multirow{2}{*}{$\begin{array}{l}\text { Rentang } \\
\text { Skor }\end{array}$} & \multirow{2}{*}{ Kategori } & \multicolumn{2}{|c|}{ Jumlah } \\
\hline & & Kelas Eksperimen & Kelas Kontrol \\
\hline $81-100$ & Sangat Tinggi & 20 & 10 \\
\hline $66-80$ & Tinggi & 10 & 18 \\
\hline $56-65$ & Sedang & 0 & 2 \\
\hline $41-55$ & Rendah & 0 & 0 \\
\hline $0-40$ & Sangat Rendah & 0 & 0 \\
\hline \multicolumn{2}{|c|}{ Jumlah } & 30 & 30 \\
\hline
\end{tabular}

Berdasarkan tabel diatas, menunjukkan bahwa adanya perbedaan nilai posttest pada kelas eksperimen dan kelas kontrol, dimana pada kelas eksperimen terdapat peningkatan dibandingkan pada kelas kontrol. 
Ditinjau dari hasil pencapaian indikator pemahaman konsep yakni:

Tabel 3. Gambaran Persentase Pencapaian Indikator Pemahaman Konsep Peserta Didik

\begin{tabular}{cccc}
\hline \multirow{2}{*}{ Kelas } & \multicolumn{3}{c}{ Jumlah } \\
\cline { 2 - 4 } & $\begin{array}{c}\text { Indikator } \\
\mathbf{A}_{\mathbf{1}}\end{array}$ & $\begin{array}{c}\text { Indikator } \\
\mathbf{A}_{\mathbf{2}}\end{array}$ & $\begin{array}{c}\text { Indikator } \\
\mathbf{A}_{\mathbf{3}}\end{array}$ \\
\hline Eksperimen & $93,33 \%$ & $85,55 \%$ & $84,35 \%$ \\
Kontrol & $75,55 \%$ & $78,51 \%$ & $77,69 \%$ \\
\hline
\end{tabular}

Keterangan: $\quad A_{1}$ (Mencontohkan),

$\mathrm{A}_{2}$ (Mengklasifikasikan),

$\mathrm{A}_{3}$ (Membandingkan)

Berdasarkan peresentase skor pemahaman konsep terlihat bahwa pada kelas eksperimen tingkat pesersentase ketercapaiannya lebih tinggi daripada kelas kontrol.

Tabel 4. Data Hasil Uji Normalitas

\begin{tabular}{ccccc}
\hline Data & Eks & Kon & & Keterangan \\
\cline { 2 - 3 } & Posttest & Posttest & & $\begin{array}{c}\text { Keter } \\
X_{\text {hitung }}^{2}<X_{\text {tabel }}^{2}\end{array}$ \\
\cline { 1 - 3 } $\mathrm{N}$ & 30 & 30 & & Normal \\
$X_{\text {hitung }}^{2}$ & 7,8699 & 9,1137 & & Normal \\
$X_{\text {tabel }}^{2}$ & 11,070 & 11,070 & & \\
\hline
\end{tabular}

Uji normalitas yang digunakan pada penelitian ini ialah uji chi-kuadrat. Berdasarkan hasil uji normalitas pada Tabel 4 diketahui bahwa $X^{2}$ hitung kelas eksperimen dan kelas kontrol kurang dari $X_{\text {tabel. }}^{2}$ Berarti keputusan uji normalitas pada penelitian ini adalah data sampel berasal dari populasi berdistribusi normal.

Tabel 5. Data Hasil Uji Homogenitas

\begin{tabular}{ccccc}
\hline Data & $\boldsymbol{a}$ & $\mathbf{F}_{\text {hitung }}$ & $\mathbf{F}_{\text {tabel }}$ & $\begin{array}{c}\text { Keterangan } \\
\mathbf{F}_{\text {hitung }} \leq \mathbf{F}_{\text {tabel }}\end{array}$ \\
\hline Pretest & 0,05 & 1,12 & 1,88 & Homogen \\
Pretest & 0,05 & 1,01 & 1,88 & Homogen \\
\hline
\end{tabular}

Uji homogenitas digunakan untuk mengetahui apakah kedua kelompok data yang diteliti berasal dari populasi yang homogen atau tidak, dengan kriteria $\mathrm{F}_{\text {hitung }}<\mathrm{F}_{\text {tabel, }}$, maka data berasal dari populasi homogen. Berdasarkan Tabel 5 dapat diketahui bahwa data pemahaman konsep peserta didik yang mengikuti pembelajaran dengan model pembelajaran kooperatif tipe NHT dan peserta didik yang mengikuti pembelajaran konvensional memiliki pada taraf nyata 0,05 yang berarti Ho diterima, yang berarti tidak ada perbedaan varians antara data pemahaman konsep peserta didik menggunakan model pembelajaran kooperatif tipe NHT dan pembelajaran konvensional atau kedua populasi memiliki varians yang sama. Berdasarkan hasil uji prasyarat, disimpulkan bahwa kedua kelompok data berasal dari populasi yang berdistribusi normal dan homogen, maka uji hipotesis menggunakan uji-t. 
Tabel 6. Data Hasil Uji Hipotesis

\begin{tabular}{cccc}
\hline Data & $\boldsymbol{t}_{\text {hitung }}$ & $\mathbf{t}_{\text {tabel }}$ & $\begin{array}{c}\text { Keterangan } \\
\mathbf{t}_{\text {hitung }}<\mathbf{t}_{\text {tabel }}\end{array}$ \\
\hline Pretest & $-1,91$ & 1,67 & $\mathrm{H}_{\mathrm{o}}$ diterima dan $\mathrm{H}_{\mathrm{a}}$ ditolak \\
Posttest & 3,89 & 1,67 & $\mathrm{H}_{\mathrm{o}}$ ditolak dan $\mathrm{H}_{\mathrm{a}}$ diterima \\
\hline
\end{tabular}

Kriteria pengujian hipotesis adalah jika $t_{\text {hitung }}>t_{\text {tabel, }}$, maka $H_{o}$ ditolak dan jika $t_{\text {hitung }}<t_{\text {tabel }}$ maka $\mathrm{H}_{\mathrm{o}}$ diterima. Hasil uji-t pemahaman konsep diperoleh pada saat pemberian posttest yakni $t_{\text {hitung }}<$ $t_{\text {tabel }}$ yang berarti $\mathrm{H}_{\mathrm{o}}$ ditolak dan $\mathrm{H}_{\mathrm{a}}$ diterima. Oleh karena itu, dapat disimpulkan bahwa terdapat pengaruh model pembelajaran kooperatif tipe Numbered Head Together (NHT) terhadap pemahaman konsep Peserta Didik Kelas VII SMP Negeri 18 Makaassar (Studi Pada Materi Pokok Tata Surya).

Data yang diperoleh pada analisis lembar observasi keterlaksanaan model pembelajaran kooperatif tipe Numbered Head Together (NHT) yaitu pada pertemuan pertama 100\%, pertemuan kedua $100 \%$, dan pertemuan ketiga 100\%. Dari data tersebut menunjukkan bahwa semua langkah dalam pembelajaran terlaksana sesuai dengan model pembelajaran.

\section{Pembahasan}

Penelitian ini dimaksudkan untuk mengetahui pengaruh model pembelajaran kooperatif tipe Numbered Head Together (NHT) terhadap pemahaman konsep peserta didik kelas VII SMPN 18 Makassar studi pada materi pokok tata surya. Sebelum dilakukannya penelitian terlebih dahulu tes pemahaman konsep di uji empiris pada kelas VIII 8 dimana pada hasil analisis diperoleh bahwa dari 30 item soal yang diuji cobakan terdapat 23 item soal yang valid dan 7 invalid namun untuk mencukupi soal yang ada maka diambil dua soal untuk direvisi kembali sehingga tes pemahaman konsep yang diberikan pada saat penelitian berjumlah 25 item. Untuk mengetahui pengaruh pembelajaran tersebut, diambil dua kelas sebagai kelompok sampel yaitu kelas eksperimen dan kelas kontrol. Kelas eksperimen dilakukan pembelajaran dengan model pembelajaran kooperatif tipe Numbered Head Together (NHT) sedangkan kelas kontrol dilakukan pembelajaran dengan model pembelajaran konvensional. Dari kedua kelas tersebut diberikan pretest dan posttest.

Berdasarkan analisis statistik secara deskriptif terlihat bahwa pemahaman konsep peserta didik kelas VII SMPN 18 Makassar pada kelas eksperimen dan berbeda pada kelas kontrol. Hal ini dapat dilihat dari nilai taksiran rata-rata yang diperoleh, dimana nilai rata-rata populasi kelas eksperimen termasuk dalam kategori sangat tinggi, nilai rata-rata populasi kelas kontrol termasuk kategori tinggi. Untuk lebih jelasnya dapat dilihat pada tabel 4.2.

Untuk memperkuat hasil analisis deskriptif diatas maka dilakukan analisis statistik inferensial untuk membuktikan hipotesis yang diajukan. Dengan demikian diperoleh hasil analisis Uji-t, membuktikan bahwa pada pretest $\mathrm{H}_{\mathrm{o}}$ diterima dan $\mathrm{H}_{\mathrm{a}}$ ditolak dan pada posttest $\mathrm{H}_{\mathrm{o}}$ ditolak dan $\mathrm{H}_{\mathrm{a}}$ diterima yang berarti bahwa terdapat perbedaan pemahaman konsep peserta didik yang diajar menggunakan model pembelajaran kooperatif tipe Numbered Head Together (NHT) dan yang diajar dengan model pembelajaran konvensional. Dari nilai yang diperoleh peserta didik terdapat 83,33\% ketercapaian KKM disekolah namun kriteria ini tidak mutlak dijadikan acuan dikarenakan jenis soal tes pemahaman konsep hanya berada pada ranah kognitif $C_{2}$ dan belum mencakup ranah kognitif lainnya.

Kerangka pikir pada awal penelitian menunjukkan optimisme peneliti melihat akan adanya perbedaan pemahaman konsep yang terbangun pada pembelajaran yang menggunakan model pembelajaran kooperatif tipe Numbered Head Together (NHT) dengan pembelajaran menggunakan model konvensional yang diterapkan di SMPN 18 Makassar. Hal ini terbukti peserta didik yang diberi perlakuan mampu memperlihatkan keseriusan dan semangat dalam belajar. $\mathrm{HI}$ ini ternyata 
berdampak pada hasil pemahaman konsep peserta didik. Dan akhirnya diperoleh bahwa pembelajaran dengan menggunakan model pembelajaran kooperatif tipe Numbered Head Together (NHT) memberikan hasil pemahaman konsep yang berbeda daripada pembelajaran dengan model konvensional.

Perbedaan ini tidak terlepas dari adanya efek perlakuan pada kelas eksperimen, dimana pada penggunaan model NHT, pendidik berusaha menekankan aktivitas peserta didik secara maksimal dalam proses belajar mengajar. Seluruh aktivitas yang dilakukan peserta didik diarahkan untuk mencari dan menemukan jawaban sendiri dari suatu yang dipertanyakan, dengan diberikan nomor kepala dan pada saat proses menjawab pertanyaan pendidik akan menyebutkan nomor kepala yang akan menjawab soal, nomor kepala yang disebutkan harus menjawab pertanyaan didepan kelompok lain sehingga peserta didik dapat menumbuhkan rasa percaya dirinya, dan informasi yang diperoleh dapat bertahan lama, memperjelas dan mempermudah konsep yang bersifat abstrak dan mempermudah dalam pemecahan masalah sehingga peserta didik dapat dengan mudah menyelesaikan tes pemahaman konsep

Indikator yang diharapkan dapat dipahami oleh peserta didik, hasil analisis menunjukkan bahwa peserta didik lebih mudah menyelesaikan tes pemahaman konsep indikator $A_{1}$ (Mencontohkan, Menemukan contoh atau ilustrasi tentang konsep atau prinsip) dibandingkan indikator $\mathrm{A}_{2}$ (Mengklasifikasikan, Menentukan sesuatu dalam satu kategori) dan indikator $\mathrm{A}_{3}$ (Membandingkan, Menentukan hubungan antara dua ide, dua objek, dan semacamnya). Hal tersebut dapat terlihat dari persentase skor pemahaman konsep peserta didik yang menggambarkan bahwa persentase paling tinggi berada pada indikator $A_{1}$ (Mencontohkan, Menemukan contoh atau ilustrasi tentang konsep atau prinsip) kemudian indikator $A_{2}$ (Mengklasifikasikan, Menentukan sesuatu dalam satu kategori) dan indikator $\mathrm{A}_{3}$ (Membandingkan, Menentukan hubungan antara dua ide, dua objek, dan semacamnya). Pencapaian indikator pemahaman konsep ditunjang oleh keterlaksanaan pembelajaran, hal ini disebabkan karena pencapaian pada keterlaksanaan pembelajaran mencapai persentase $100 \%$. Hal ini menujukkan bahwa semua langkah pada pembelajaran dilakaksanakan pada proses mengajar.

Perbedaan tersebut disebabkan karena pada pembelajaran dengan model kooperatif tipe NHT seluruh aktivitas yang dilakukan peserta didik diarahkan untuk mencari dan menemukan jawabannya sendiri dari suatu pertanyaan dan memberikan tanggungjawab yang sama pada masing-masing peserta didik dalam mempersentasekan jawabannya, sehingga materi yang diinformasikan lebih berkesan atau tahan lama, memperjelas dan mempermudah konsep yang bersifat abstrak. Berdasarkan uraian tersebut, maka tampak bahwa pengaruh model pembelajaran Kooperatif tipe Numbered Head Together (NHT) dapat meningkatkan pemahaman konsep peserta didik sehingga dapat dijadikan alternatif dalam proses pembelajaran. Hasil penelitian ini selaras dengan hasil-hasil penelitian terdahulu yang telah dilakukan seperti temuan Ratnasari (2015), dan Ilyasari (2013).

\section{KESIMPULAN}

Berdasarkan hasil penelitian yang telah dilakukan dapat disimpulkan sebagai berikut:

1. Tingkat pemahaman konsep peserta didik kelas VII SMPN 18 Makassar tahun ajaran 2016/2017 yang diajar menggunakan model pembelajaran kooperatif tipe Numbered Head Together (NHT) berada pada kategori sangat tinggi.

2. Tingkat pemahaman konsep peserta didik kelas VII SMPN 18 Makassar tahun ajaran 2016/2017 yang diajar menggunakan model pembelajaran konvensional berada pada kategori tinggi.

3. Terdapat pengaruh model pembelajaran Kooperatif Tipe Numbered Head Together (NHT) terhadap pemahaman konsep peserta didik kelas VII SMP Negeri 18 Makassar (Studi Pada Materi Pokok Tata Surya) tahun ajaran 2016/2017. 


\section{DAFTAR PUSTAKA}

Anderson, L. W., \& Krathwohl, D. R. 2010. Kerangka Landasan Untuk Pembelajaran, Pengajaran, dan Asesmen; Revisi Taksonomi Bloom. Yogyakarta: Pustaka Belajar.

Huda, M. 2011. Cooperatif Learning. Yogyakarta: Pustaka Pelajar.

Ilyasari, A., Gimin, S., \& Rini, A. 2013. Pengaruh Model Pembelajaran Kooperatif Tipe Nht Terhadap Pemahaman Konsep Matematis Siswa. Jurnal pendidikan matematika unila. Vol 1, No 7.

Isjoni. 2013. Cooperative Learning. Bandung : Alfabeta.

Ratnasari, S., Allesius, M., \& Wita, S. 2017. Pengaruh Model Pembelajaran Kooperatif Tipe Numbered Heads Together (NHT) Terhadap Peningkatan Keterampilan Sosial Dan Pemahaman Konsep Siswa Dalam Pembelajaran IPA. Jurnal pendidikan ilmu pengetahuan alam. Vol 6, No 1.

Sanjaya, W. 2006. Strategi Pembelajaran Berorientasi Standar Proses Pendidikan. Bandung: KencanaPrenada Media Group.

Sitorus. 2012. Komparasi Hasil Belajar Siswa Melalui Penerapan Dua Model Pembelajaran Komparatif pada Materi Biosfer Kelas XI SMA Negeri 3 Kisaran. Kota Kisaran. Diakses pada tanggal 22 Januari 2017.

Susanto, A. 2012. Perkembangan Anak Usia Dini. Jakarta: Kencana Prenada Media Group.

Taniredja, T., Faridli, M., \& Harmianto, S. 2012. Model Pembelajaran Inovatif dan Efektif. Bandung: Alfabeta.

Trianto. 2012. Mendesain Model Pembelajaran Inovatif-Progresif. Jakarta: Kencana Predana Media Group.

Tung, K. Y. 2000. Pembelajaran dan Perkembangan Belajar. Bandung: Indeks.

Received, 20 June 2018

Accepted, 20 January 2019

\section{Ratnawaty Mamin}

\section{Sudarto}

\section{Rahmita}

Alumni Prodi Pendidikan IPA Universitas Negeri Makassar 